\title{
The influence of lipoprotein(a) on fibrinolytic activity
}

\author{
Rahajuningsih Dharma Setiabudy, Marzuki Suryaatmadja, Fifi Henrika
}

\begin{abstract}
Abstrak
Lipoprotein (a) adalah suatu lipoprotein plasma yang mempunyai struktur dan komposisi yang mirip dengan lipoprotein berdensitas rendah $(L D L)$ dengan tambahan apo(a) yang terikat pada apo $B_{100}$. Struktur apo(a) mirip dengan plasminogen, suatu proenzim dalam sistem fibrinolitik. Oleh karena kemiripan ini, diduga Lp(a) dapat menghambat aktivitas plasminogen dan menurunkan aktivitas fibrinolitik. Penelitian ini bertujuan untuk membuktikan bahwa penambahan Lp(a) ke dalam plasma normal dapat menghambat aktivitas fibrinolitik. Subyek penelitian terdiri atas 4 orang sehat dengan kadar fibrinogen, aktivitas plasminogen dan masa lisis bekuan euglobulin dalam batas normal. Pada percobaan pertama, penambahan Lp(a) dilakukan sebelum sentrifugasi untuk memperoleh endapan euglobulin, sedang pada percobaan kedua Lp(a) ditambahkan pada endapan euglobulin. Sebagai kontrol, masa lisis bekuan euglobulin dikerjakan pada plasma yang ditambahkan $\mathrm{NaCl}$ 0,9\% dengan volume yang sama seperti Lp(a). Hasil penelitian menunjukkan bahwa pada percobaan pertama tidak ada bekuan yang terbentuk. Diduga Lp(a) dapat mengikat fibrinogen dan keduanya berada di supernatan, sehingga tidak ada fibrinogen dalam endapan euglobulin yang dapat dibekukan oleh trombin. Pada percobaan kedua, sampai hari ke empat bekuan belum lisis. Kesimpulan: Penambahan Lp(a) ke dalam plasma normal dapat menghambat aktivitas sistem fibrinolitik. (Med J Indones 2004; 13: 135-9)
\end{abstract}

\begin{abstract}
Lipoprotein(a) is a plasma lipoprotein whose structure and composition are similar with low density lipoprotein (LDL) with an addition of apo(a) that is bound to apo $B_{100}$. The structure of apo $(a)$ is similar with plasminogen, a proenzym in fibrinolytic system. Due to this similarity, it is assumed that $\mathrm{Lp}(\mathrm{a})$ can inhibit plasminogen activity and decreases fibrinolytic activity. The purpose of this study is to prove that addition of $\operatorname{Lp}(a)$ to normal plasma can inhibit fibrinolytic activity. Four healthy people whose fibrinogen levels, plasminogen activities and euglobulin clot lysis time were within normal range were enrolled in this study. Fibrinolytic activity were assessed by euglobulin clot lysis time (ECLT). In the first experiment, the addition of Lp(a) was done before centrifugation to obtain euglobulin precipitates, while in the second experiment, Lp(a) was added to the euglobulin precipitates. As a control, ECLT was performed in the plasma with the addition of $\mathrm{NaCl} 0.9 \%$ in the same volume with Lp(a). The results of the study showed that in the first experiment, there was no clot formation. It is assumed that $L p(a)$ can bind fibrinogen and both of them floated in the supernatant, so there was no fibrinogen in the euglobulin precipitate that can be clotted by thrombin. In the second experiment, the clot did not dissolve until the fourth day. In conclusion, the addition of $L p(a)$ to normal plasma can inhibit the activity of fibrinolytic system. (Med J Indones 2004; 13: 135-9)
\end{abstract}

Keywords: plasminogen, fibrinogen, apo(a), euglobulin clot lysis time (ECLT)

The reports of the Household Health Survey conducted by the Ministry of Health of the Republic of Indonesia on 1985, 1992 and 1995 showed an increase tendency of coronary heart disease (CHD) as a cause of death. ${ }^{1}$ Risk factors of CHD include dyslipidemia, cigarette smoking, hypertension, diabetes mellitus, hyperuricemia, obesity and contraceptive

Department of Clinical Pathology, Faculty of Medicine, University of Indonesia / Dr. Cipto Mangunkusumo General Hospital, Jakarta, Indonesia user. $^{2,3}$ Recently, the result of several studies indicated that increase of lipoprotein (a) [Lp(a)] level is also an independent risk factor for $\mathrm{CHD}^{3-7} \mathrm{An}$ $\mathrm{Lp}$ (a) level higher than $30 \mathrm{mg} / \mathrm{dL}$ is a risk factor of myocardial infarction. ${ }^{3,8}$ In addition, the increase of $\mathrm{Lp}$ (a) is also a risk factor of stroke. ${ }^{9}$ The increase of $\mathrm{Lp}(\mathrm{a})$ is also found in diabetes mellitus and at the end stage of renal failure. ${ }^{9}$

Lipoprotein(a) in human serum was found firstly in 1963 by Berg. ${ }^{10}$ The structure and composition of Lp(a) are similar with LDL cholesterol. The lipid component is composed of cholesterol ester and 
triglyceride, while the protein component consists of apolipoprotein (a) [apo(a)] that binds to apo $\mathrm{B}_{100}$ via disulfide bonds. Lipoprotein(a) has a pro-atherogenic activity, because it has the ability to cross arterial wall and be trapped in the tunica intima. This phenomenon occurs as a result of its similarity with LDL cholesterol, and the presence of extracellular matrix component especially glycosaminoglycan which has high affinity to apo $\mathrm{B}_{100}$. ${ }^{7}$ In addition, like LDL cholesterol, Lp(a) will be oxidized and modified. The oxidized $\mathrm{Lp}(\mathrm{a})$ will be caught by scavenger receptor, and induces accumulation of intracellular cholesterol ester and foam cell formation. This is an initiation of plaque formation at the atherosclerotic site. $^{7}$

The structure of apo (a) is similar with plasminogen, a proenzyme in fibrinolytic system. Fibrinolytic system is a biochemical mechanism that functions to limit the extent of coagulation process and to reestablish normal blood flow. This system consists of plasminogen, plasminogen activators, and the inhibitors. Plasminogen, the precursor of plasmin, is a singlechain glycoprotein of $92 \mathrm{kd}$ and contains approximately $2 \%$ carbohydrate. The molecule consists of 791 amino acids, contains 24 disulfide bonds, and has five different kringles. ${ }^{11}$ The kringle, named after a Danish breakfast roll, is approximately 80 amino acid long and is held together by three internal disulfide bonds. Functionally, the kringles give to the plasminogen an ability to bind to exposed lysyl residues in fibrin, $\alpha_{2}$-antiplasmin, collagen, extracellular matrix, and cell surface receptor. ${ }^{12}$ All known plasminogen activators such as tissue plasminogen activator (t-PA), urokinase (u-PA), streptokinaseplasminogen complex, and the staphylokinase (SAK) can activate plasminogen and convert it to plasmin, by cleaving the Arg-561-Val562 bond in plasminogen. ${ }^{11}$ Kallikrein and other coagulation factors of the contact system may have low PA activity and also known as intrinsic activators. ${ }^{13}$ These proactivators exist in plasma in a zymogen form, but become activated after the contact system has been stimulated. Tissue plasminogen activator, a serine protease of $68 \mathrm{kd}$, also known as tissue-type PA, vascular PA, or extrinsic PA, is one of two physiologic PA present in human blood. It exerts its effect primarily in the vascular system and is the principal agent for the dissolution of thrombi via activation of clot-bound plasminogen to plasmin, whereas the urinary-type PA or urokinase, is reported to play a role in cell migration and tissue remodeling. Tissue-plasminogen activator has been isolated from many tissues including uterus, cardiac fibroblast, monocytes, megakaryocytes, mesothelial cells, neuronal cells, and vascular smooth muscle cells, but its principal site of synthesis is the endothelial cell. ${ }^{11}$ Inhibitors of the fibrinolytic system include $\alpha_{2}$-antiplasmin, $\alpha_{2}$-macroglobulin, plasminogen activator inhibitor-1 (PAI-1), plasminogen activator inhibitor-2 (PAI-2), C1-inhibitor, histidine-rich glycoprotein, and thrombin-activatable fibrinolysis inhibitor (TAFI). The primary inhibitor of plasmin is $\alpha_{2}-$ antiplasmin, whereas PAI-1 is the principal inhibitor of t-PA and two chain u-PA (tcu-PA). ${ }^{11}$

The activity of fibrinolytic system can be evaluated by performing global test such as whole blood clot lysis time, and euglobulin clot lysis time or by determining the levels or activities of each component such as: t-PA, PAI-1, plasminogen, $\alpha_{2}$-antiplasmin, and plasmin-antiplasmin complex, or by determining the results of fibrinolytic process, i.e. the level of fibrin degradation products (FDP, D-dimer). ${ }^{14}$

The apo(a) has $15-37$ copies of kringle 4 which is homolog with kringle 4 of plasminogen, and 1 copy of kringle 5. Due to this similarity, it is assumed that $\mathrm{Lp}(\mathrm{a})$ has an ability to inhibit plasminogen activity and to decrease fibrinolytic activity. The purpose of this study is to prove that high level of $L p(a)$ can inhibit fibrinolytic activity by adding a certain amount of $\operatorname{Lp}(\mathrm{a})$ to normal human plasma, and measuring the fibrinolytic activity by performing euglobulin clot lysis time (ECLT).

\section{METHODS}

Four healthy volunteers whose fibrinogen level, plasminogen activity, and ECLT result within normal range were enrolled in this study. For this study, 4.5 $\mathrm{mL}$ of blood was collected from each volunteer. The blood was mixed with $0.5 \mathrm{~mL}$ of sodium citrate of $1.09 \mathrm{M}$, and then was centrifuged at $1500 \mathrm{~g}$ for 10 minutes to get platelet poor plasma (PPP). The level of fibrinogen and the activity of plasminogen of each subject was determined.

The level of fibrinogen was determined by Clauss method, and the activity of plasminogen was examined by chromogenic substrate. The reagent for determination of fibrinogen level and plasminogen activity were purchased from Behring. If one or both tests indicated abnormal result, the subject should be excluded. If the results of both tests were within normal range, then the ECLT was performed. 
The principle of ECLT is to determine the time needed by the clot to dissolve completely. ${ }^{14}$ The procedure consists of several steps. Step I is precipitation of the euglobulin fraction by decreasing the temperature and the $\mathrm{pH}$ of plasma by addition of cool distilled water and $1 \%$ acetic acid solution. The euglobulin fraction contains fibrinogen, plasminogen, and plasminogen activator. The inhibitor of fibrinolytic system is present in the supernatant and should be discarded. Step II is fibrin clot formation by the addition of thrombin solution and incubation at $37^{\circ} \mathrm{C}$. Step III is the measurement of the time needed by the clot to dissolve completely.

Reagent for ECLT consists of 1\% acetic acid solution, veronal buffer $\mathrm{pH} 7.2$, thrombin solution of $50 \mathrm{NIH}$ $\mathrm{U} / \mathrm{mL}$, and cool distilled water $\left(2^{\circ}-8^{\circ} \mathrm{C}\right)$.

Procedure of ECLT:

1. Pipette $0.5 \mathrm{ml}$ of PPP to a tube containing $6 \mathrm{ml}$ of cool distilled water.

2. Add $0.1 \mathrm{ml}$ of $1 \%$ cool acetic acid solution until the $\mathrm{pH}$ of solution is 5.9.

3. Put the tube in a refrigerator and leave it for 10 minutes.

4. Then centrifuge the tube at $1500 \mathrm{x} \mathrm{g}$ for 10 minutes.

5. Discard the supernatant, invert the tube to dry the inner wall.

6. Dissolve the precipitate in $0.35 \mathrm{ml}$ of veronal buffer $\mathrm{pH}$ 7.2.

7. Transfer the content of the tube to a glass tube of 12 x $100 \mathrm{~mm}$ size.

8. Add $25 \mu \mathrm{L}$ of thrombin solution until clot formation occur.

9. Incubate the tube in $37^{\circ} \mathrm{C}$ and every 30 minutes check it for complete lysis. Note the time needed for complete lysis.

If the results of ECLT were within normal range (2 4 hours), then the subject could be included in this study.

In order to know whether $\mathrm{Lp}(\mathrm{a})$ can inhibit fibrinolytic activity, ECLT was performed on plasma after the addition of a certain level of $L p(a)$ solution. Since it was not known whether $\operatorname{Lp}(a)$ existed in the precipitate or in the supernatant after centrifugation, two trials were done. In the first, $\operatorname{Lp}(\mathrm{a})$ was added to the plasma prior to centrifugation, and in the second trial, $\mathrm{Lp}$ (a) was added to the euglobulin fraction after centrifugation and separation of the supernatant. In this study, $\mathrm{Lp}$ (a) solution of $48.3 \mathrm{mg} / \mathrm{dL}$ and of 93.8 $\mathrm{mg} / \mathrm{dL}$ were originated from moderate and high Lp(a) standard respectively made by Daiichi, with catalogue no. 023 RDX. In the first trial, ECLT was done on plasma of subject no 1 and 2 with the addition of $0.5 \mathrm{~mL}$ of $\mathrm{Lp}$ (a) solution of $48.3 \mathrm{mg} / \mathrm{dL}$ prior to centrifugation, while to plasma of subject no 3 and $4 \mathrm{Lp}$ (a) solution of $93.8 \mathrm{mg} / \mathrm{dL}$ was added. In the second trial, $0.5 \mathrm{~mL}$ of $\mathrm{Lp}(\mathrm{a})$ solution of 48.3 $\mathrm{mg} / \mathrm{dL}$ was added to the euglobulin precipitate of subject no 1 and 2, and $0.5 \mathrm{~mL}$ of $\mathrm{Lp}(\mathrm{a})$ solution of $93.8 \mathrm{mg} / \mathrm{dL}$ was added to euglobulin precipitate of subject no 3 and 4. As a control, instead of $\mathrm{Lp}(\mathrm{a})$ solution, $\mathrm{NaCl} 0.9 \%$ in the same volume was added to the plasma and ECLT measurements were performed.

\section{RESULTS}

In this study, all cases had normal fibrinogen level, plasminogen activity, and ECLT (Table 1). Addition of $\mathrm{NaCl} 0.9 \%$ to each plasma resulted in shortening of ECLT, all clots dissolved completely in 30 minutes.

The first trial revealed that after the addition of thrombin solution to the euglobulin precipitate (with addition of $L p(a)$ prior to centrifugation), no fibrin clot was formed. In the second trial, where $\operatorname{Lp}(\mathrm{a})$ solution was added to the euglobulin precipitate, at the fourth day all of the clots still existed or they had not dissolved completely.

Table 1. Fibrinogen level, plasminogen activity, and ECLT with and without $L p(a)$ addition

\begin{tabular}{lcccc}
\hline Subjects & $\begin{array}{c}\text { Fibrinogen } \\
(\mathrm{mg} / \mathrm{dL})\end{array}$ & $\begin{array}{c}\text { Plasminogen } \\
\text { activity }(\%)\end{array}$ & \multicolumn{2}{c}{ ECLT (hour) } \\
\cline { 4 - 5 } & & & $\begin{array}{c}\text { without Lp(a) } \\
\text { addition }\end{array}$ & $\begin{array}{c}\text { with Lp(a) } \\
\text { addition }\end{array}$ \\
\hline no.1 & 327 & 126.7 & 3 & $>96$ \\
no.2 & 201 & 129.0 & 2.5 & $>96$ \\
no.3 & 320 & 114.0 & 3 & $>96$ \\
no.4 & 270 & 131.6 & 2.5 & $>96$ \\
\hline
\end{tabular}

$\mathrm{Lp}(\mathrm{a})=$ lipoprotein $(\mathrm{a})$

ECLT $=$ euglobulin clot lysis time 


\section{DISCUSSION}

Fibrinolytic system plays an important role in thrombosis prevention, since plasmin as a proteolytic enzyme can destroy fibrin by enzymatic process. In normal condition, there is no plasmin in the circulation, because it will be neutralized by antiplasmin. However, in the circulation we can find plasminogen, the precursor of plasmin. Plasminogen activator such as t-PA or urokinase will activate plasminogen and convert it to plasmin. Apolipoprotein (a) of $\mathrm{Lp}$ (a) has similar structure with plasminogen. Due to this similarity it is assumed that $\operatorname{Lp}(a)$ can inhibit plasminogen activity (Figure 1).

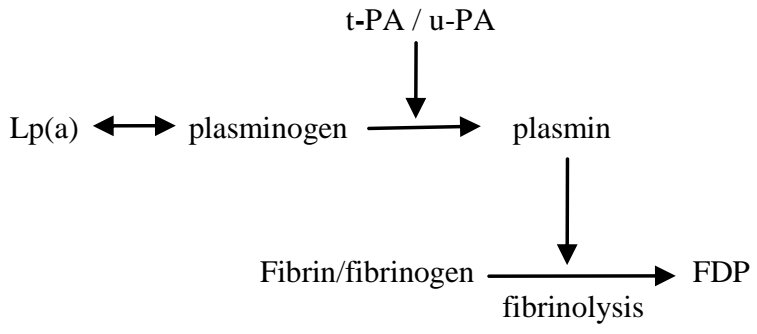

Figure 1. The role of $\operatorname{Lp}(a)$ on fibrinolytic activity

t-PA = tissue plasminogen activator

u-PA = urokinase type plasminogen activator

$\mathrm{Lp}(\mathrm{a})=$ lipoprotein (a)

FDP = fibrin/fibrinogen degradation products

In the first trial of this study where $\operatorname{Lp}(a)$ was added to the plasma prior to centrifugation, there was no fibrin clot formation after the addition of thrombin solution to the euglobulin fraction. The failure in fibrin clot formation suggested that the amount of fibrinogen in the euglobulin precipitate was too low. This condition might be due to the presence of lysine binding site in the kringle of $\mathrm{Lp}$ (a) molecule that enables it to bind fibrinogen, and probably both of them were present in the supernatant that was discarded. In the second trial, where $\mathrm{Lp}$ (a) was added to the euglobulin precipitate, prolonged ECLT was observed, i.e. at the fourth day fibrin clot still existed. It means that $\mathrm{Lp}$ (a) can inhibit fibrinolytic activity. Probably this phenomenon happened as a result of the ability of $\mathrm{Lp}(\mathrm{a})$ to bind plasminogen activator via its lysine binding site. According to Loscalzo and Edelberg, Lp(a) competes with plasminogen and t-Pa for binding to fibrin and may thereby exert an antifibrinolytic effect. ${ }^{15,16}$ Binding of t-PA to $\mathrm{Lp}(\mathrm{a})$ with the resulting inability to activate plasminogen also has been described. Liu and colleagues found that $\mathrm{Lp}(\mathrm{a})$ can form covalent ester bonds with fibrin and endothelial cells. ${ }^{17}$ Covalent binding was attenuated when $\operatorname{Lp}(\mathrm{a})$ was pretreated with diisopropyl fluorophosphate (DFP), suggesting that the serine residues in the pseudo active site of Lp(a) was involved. ${ }^{17}$ Oxidation of Lp(a) results in increased competitiveness for plasminogen binding to extracellular matrix and to endothelial cells. ${ }^{18,19}$ Endogenous thrombus lysis was inhibited in a concentration dependent manner by apo(a), and t-PA mediated lysis of thrombi was significantly decreased in rabbits receiving higher doses of apo(a). ${ }^{20}$ In this study, the addition of $\mathrm{NaCl} 0,9 \%$ to the plasma resulted in shortening of ECLT. This phenomenon may be caused by dilution effect or ionic strength changes induced by $\mathrm{NaCl}$ solution.

In conclusion, the result of this experiment indicated that the addition of $\mathrm{Lp}(\mathrm{a})$ to normal human plasma can inhibit fibrinolytic activity.

As an attempt to elucidate the mechanism of fibrinolytic inhibition by $\operatorname{Lp}(\mathrm{a})$, it is recommended to study the effect of $L p(a)$ on the activity of plasminogen and t-PA using a sufficient number of subjects.

\section{Aknowledgement}

We thank PT Sumber Mitra Agung Jaya, the distributor of Daiichi Pure Chemicals Company for providing Lipoprotein(a).

\section{REFERENCES}

1. Mihardja L, Soemantri S, Djaja S, Setyowati T. Survei Kesehatan Rumah Tangga : Mortalitas penyakit kardiovaskular serta beberapa factor yang berkorelasi. Jakarta: Badan Lit Bang Kes Dep Kes RI; 1997. p1.

2. Suyono S. Patogenesis aterosklerosis. Simposium Perkembangan Baru dalam Penatalaksanaan Hipertensi dan Aterosklerosis; 1992 June 20; Jakarta, Indonesia.

3. Rhoads GG, Dahlen G, Berg K, Morton NE, Dannenberg AL. Lipoprotein(a) as risk factor for myocardial infarction. Jama 1986; 256(18): 2540-4.

4. Sandkamp M, Funke H, Schulte H, Kohler E, Assmann G. Lipoprotein(a) is an independent risk factor for myocardial infarction at young age. Clin Chem 1990;36(1):20-3.

5. Ridker PM, Hennekens CH, Stampfer MJ. A Prospective study of lipoprotein (a) and risk factor of myocardial infarction. Jama 1993;270(18):2195-9.

6. Moliterno DJ, Lange AR, Meidell RS, Willard JE, Leffert $\mathrm{CC}$, Gerard RD, et al. Relation of plasma lipoprotein (a) 
to infarct artery potency in survivor of myocardial infarction. Circulation 1993; 88(3):935-40.

7. Schaefer EJ, Fava SL, Jenner JL, Mc Namara JR, Odovas JM, Davis CE. Lipoprotein (a) level and risk factor of coronary heart disease in men. Jama 1994;27(13):9991003.

8. Kronenberg F, Steinmetz A, Kostner GM, Diepplinger. Lipoprotein(a) in health and disease. Clin Lab Sci 1996;33(6):495-510.

9. Kronenberg F, Steinmetz A, Kostner GM, Diepplinger. Lipoprotein(a) in health and disease. Clin Lab Sci 1996;33(6):513-43.

10. Berg K. A new serum type in man: The Lp system. Acta Pathol Microbiol Scand 1963;59:362-82.

11. Bachmann F. Plasminogen-plasmin enzyme system. In: Colman RW, Hirsh J, Marder VJ, Clowes AW, George JN, editors. Hemostasis and Thrombosis. Basic Principles and Clinical Practice. $4^{\text {th }}$ ed. Philadelphia: Lippincott Williams \& Wilkins; 2001. p. 275-330.

12. Wiman B, Wallen P. The specific interaction between plasminogen and fibrin. A physiological role of the lysine binding site in plasminogen. Thromb Res. 1977;10:21322.

13. Binnema DJ, Dooijewaard G, Iersel JJL. The contact system dependent plasminogen activator from human plasma. Identification and characterization. Thromb Haemost 1990;64:390-7.
14. Ens GE. Laboratory evaluation of fibrinolysis. In StieneMartin EA, Lotspeich-Steininger CA, Koepke JA, editors. Clinical Hematology Principle, Procedure, Correlation. $2^{\text {nd }}$ ed. Philadelphia: Lippincott Company; 1998. p 650-1.

15. Loscalzo J, Weinfeld M, Fless GM, Scanu AM. Lipoprotein(a), fibrin-binding, and plasminogen activation. Arteriosclerosis 1990;10:240-5.

16. Edelberg J, Pizzo SV. Lipoprotein (a) regulates plasmin generation and inhibition. Chem Phys Lipids 1994;67:363-8.

17. Liu JN, Kung W, Harpel PC, Gurewich V. Demonstration of covalent binding of lipoprotein(a) to fibrin and endothelial cells. Biochemistry 1998;37: 3949-54.

18. Pekelharing HL, Kleinveld HA, Duif PF, Bouma BN, van Rijn HJ. Modification of lipoprotein (a) by oxidation or desialylation influences its ability to compete with plasminogen for binding to the extracellular matrix. Blood Coagul Fibrinolysis 1996;7:641-9.

19. Ren S, Man RYK, Angel A, Shen GX. Oxidative modification enhances lipoprotein (a)-induced overproduction of plasminogen activator inhibitor-1 in cultured vascular endothelial cells. Atherosclerosis 1997;128:1-10.

20. Biemond BJ, Friederich PW, Koschinsky ML, Levi M, Sangrar W, Xia J, et al. Apolipoprotein(a) attenuates endogenous fibrinolysis in the rabbit jugular vein thrombosis model in vivo. Circulation 1997;96:1612-5. 